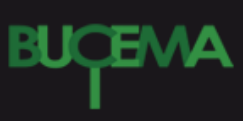

Bulletin du centre d'études médiévales d'Auxerre | BUCEMA

Hors-série $n^{\circ} 7 \mid 2013$

Les nouveaux horizons de l'ecclésiologie : du discours clérical à la science du social

\title{
Dissidence and Renewal : Developments in late medieval ecclesiology
}

Thomas Prügl

\section{(2) OpenEdition}

Journals

Édition électronique

URL : https://journals.openedition.org/cem/12782

DOI : $10.4000 /$ cem. 12782

ISSN : 1954-3093

Éditeur

Centre d'études médiévales Saint-Germain d'Auxerre

Référence électronique

Thomas Prügl, « Dissidence and Renewal : Developments in late medieval ecclesiology », Bulletin du centre d'études médiévales d'Auxerre | BUCEMA [En ligne], Hors-série $n^{\circ} 7$ | 2013, mis en ligne le 21 mars 2013, consulté le 02 mars 2023. URL : http://journals.openedition.org/cem/12782 ; DOI : https:// doi.org/10.4000/cem. 12782

Ce document a été généré automatiquement le 2 mars 2023.

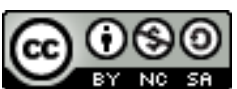

Creative Commons - Attribution - Pas d'Utilisation Commerciale - Partage dans les Mêmes Conditions 4.0 International - CC BY-NC-SA 4.0

https://creativecommons.org/licenses/by-nc-sa/4.0/ 


\section{Dissidence and Renewal : Developments in late medieval ecclesiology}

Thomas Prügl

\section{Introduction}

1 In May 1414, Jean Gerson, the famous chancellor of the University of Paris, sent a letter to Conrad of Vechta, the archbishop of Prague, to express concerns about the widespread teachings of Wyclif in the capital of Bohemia, exhorting the bishop "to root out the heresies with their authors, and cast them into the fire". After Conrad had sent copies of the works of Jan Hus to Gerson, among others the recently published De ecclesia, the Chancellor confirmed his verdict, saying that the errors should be exterminated magis igne et gladio quam curiosa raciocinacione. Among the "most pernicious errors" Gerson singled out one in particular: That someone who existed in mortal sin (malus sive praescitus) had no jurisdiction or power above other Christians. The Chancellor, who had been reflecting and writing intensively on ecclesiastical power for years in order to find solutions for the great schism, was particularly upset about the blatant erosion of the auctoritas ecclesiastica in Jan Hus' writings. The Bohemian reformer had combined Donatism with predestination ecclesiology in order to criticize the authority of the Church and to escape the disciplinary actions started against him. So reading Hus' principal work on the Church did not make Gerson welldisposed for the Bohemian at the Council of Constance, which started only a few months later. The end of the trial that followed is well-known: Hus was condemned a heretic and, on July 6,1415 , burnt at the stake. ${ }^{1}$

Gerson and Hus - both representing the great ideal of church reform in the late Middle Ages - aspired to an improvement of society and moral life by increasing the commitment to the religious life. However, as much as the reformer from Paris and the rebel from Prague agreed upon the need of reform, there could not be greater distance 
between their respective understanding of Church and ecclesiology. While Gerson worked insistently to elaborate a renewed, more biblical foundation of ecclesiastic authority, which should rebut hierocratic and other absolutistic tendencies in $14^{\text {th }}$ century papalism, Hus put into question basically any idea of institutionalized ecclesiastic authority. ${ }^{2}$ Reform and ecclesiology, the two dominating themes in the later Middle Ages, are obviously as related to each other than ecclesiology and heresiology. Despite its manifold crises the late medieval period was enormously productive in terms of ecclesiology. It seems quite plausible that those crises and the various antagonisms that emerged during the period from 1300 to 1450 fueled such productivity. In my paper, I want to substantiate this suggestion, looking at three different controversies in the first half of the $15^{\text {th }}$ century. These controversies were occasions for ecclesiological encounter between "orthodoxy" and "heterodoxy". The first took place in Prague around the year 1412, precisely when Hus published his De ecclesia. The second took place at the Council of Basel in the years 1433/34, when the Council and the Hussites defended their theological differences and discussed possible ways of reconciliation, while at the same time the papacy undermined the conciliar claims of superiority. The third is to situate in Rome around the years 1450-53, when conciliarism seemed to be ultimately defeated by a reinvigorated papalism, gaining strength after an exhaustive fight for superiority and sovereignty.

Textbooks of church history tend to distinguish two major narratives in the later medieval period. The first narrative would describe the Great Western Schism as the most dangerous crisis of the medieval papacy. This schism would have provoked an accelerated emergence of conciliarism as the most promising strategy to solve the schism and to reestablish church unity, with the councils of Pisa, Constance and Basel as the constitutional devices to develop and to test conciliarism as the more stable and reliable form of Church government. So the goal of conciliarism would have been to turn papal monarchy into some sort of conciliar aristocracy. The second narrative, only loosely related to the first, would describe the Hussite movement as the extension of a larger reform movement against the constitutional church. Such movement started already with the Francsican Spirituals - if not with the Waldensians - and reached a second climax with John Wyclif, who entertained the radical ideas of Marsilius of Padua to substitute the hierarchical papal ecclesiology by a return to the "primitive church". Wyclif's ideas had a major political impact on the Bohemian reform when Hussitism changed the religious landscape of Europe in the so-called "first reformation" or reformation of the $15^{\text {th }}$ century. As distinct and unrelated these two narratives seem to be - the first has more preference among Catholic students, while the second speaks more to a Protestant audience - they are closely connected if looked at from the standpoint of ecclesiology and if conceived as occasions of accelerated doctrinal development.

\section{Prague 1409 - 1413}

4 The reform program of Jan Hus had a number of objectives: moral, pastoral, spiritual and, last but not least, nationalistic. However, from 1409 on, Hus paid greater attention to the question of the Church as such, its nature and theology. This was about the time when he wrote his De ecclesia. Heavily influenced by John Wyclif's work of the same title, Hus developed in this text his particular understanding of predestination 
ecclesiology. For him, the Church was the universitas praedestinatorum consisting of the true faithful in the past, present and future time. ${ }^{3}$ Since one of his goals was to restore holiness within the Church, it was fitting for Hus to conceive of the Church as the pure and perfect bride of Christ "without spot and wrinkle" (sine macula et ruga, Eph 5:27), which consisted of the predestined only. Within such ecclesiology, the Church receives its identity from the future, eschatological perfection of the Church to be realized at the end of times. Only then, in the final judgment, all the saints along with the reject will become manifest. Compared to this perfect and - in the proper sense - "real" status of the Church, the ecclesia militans dwelling in this world and awaiting the final judgment cannot claim to be the true church because she is not perfect, in terms of both time and holiness. The Church in this time undergoes constant change; she is unable to provide ultimate certainty regarding the salvation of the faithful. Salvation, though depending on faith and good moral behavior during this time, remains a future and eschatological hope. Such ideas did not sound strange to medieval ears, since they echoed the basically Augustinian understanding of the Church as a reality in suspense between the 'now' and the 'then'. Hus and Wyclif, however, concluded from the preliminary nature of the Church to the validity of ecclesiastical authority, particularly the authority of ecclesiastical office holders. Authority requires perfection; consequently binding authority is part of the perfection of the Church; its exercise depends on a holy, just life on part of the office holder. ${ }^{4}$ Accordingly, a bishop or pope can claim authority only if and when he is leading a just and holy life; only then he deserves to be obeyed. Since no one in this world can guarantee the holiness of the church officials, their authority is constantly wavering and prone to suspicion. Neither Hus nor Wyclif considered such uncertainty regarding the reliability of the ecclesiastical leaders a major problem because the Church is guided at any moment by its true head, Christ. Furthermore they deemed the commitment to a holy, morally sound life more important for salvation than institutional and juridical aspects of Church membership.

5 Hus' ecclesiology was clearly dependent on Wyclif's, the first medieval theologian to develop a coherent predestination ecclesiology. ${ }^{5}$ Yet, Hus was first of all impressed by Wyclif's consequent biblical style and argumentation. Ecclesiology, the idea and form of Church, has to be gathered from biblical data and biblical models only. ${ }^{6}$ Nevertheless late medieval predestination ecclesiology was attractive because of its inherent critique of contemporary church practice and of papal government. Hus emphasized that no one among the apostles, not even Peter, dared to call himself caput ecclesiae, since Christ alone is head of the Church. Consequently the pope has no legitimate right to claim this prerogative for himself either, unless he commits a blasphemy. ${ }^{7}$ Moreover, if a person is divinely "foreknown" (praescitus), i.e. if this person will miss the eternal life and ultimately merit eternal damnation, he (or she) will never be able to hold legitimate authority in the Church, since ecclesiastic authority can be exercised only by true members of the Church. ${ }^{8}$ Hus's notion of Church followed a strict dualism: On the one hand, there is the Church of the righteous, which is the holy Church, having Christ as her head. On the other hand, there is the ecclesia malignantium, whose head is the devil. That church consists of the presciti, of those who will not inherit the Kingdom of God and who in their final destiny are "foreknown" by God. interested in a serious reform of the Church, focusing on a betterment of moral 
behavior among his compatriots. He became more and more suspicious about church authority, questioning its validity and competence, when the local archbishop Zbynĕk of Prague turned against him. Besides this biographical aspect, i.e. to justify own actions of disobedience, Hus was also upset about the abuse of ecclesiastical authority for the sake of secular goals and even more about the widespread practice to raise money for questionable ends by aggressively promoting indulgences. The indulgence to finance the "crusade" against Ladislaus of Naples infuriated the Bohemian reformer enormously. He considered such mingling of secular and spiritual goals a cynical manifestation of a perverted papal authority, playing games with religious sentiments. One has to understand Hus' contempt of the Roman Church against such backdrop.

7 Chapter 7 of Hus' De ecclesia was a blatant attack on the Roman Church, understood as pope and cardinals, but he did so by theological argumentation: If it is true that the ecclesia romana deserves particular veneration and therefore enjoys greater privileges than other churches, such "holy Roman church" cannot consist of Pope and cardinals because they are fallible. In order to demonstrated the unreliability of the papacy, Hus reminded his readers of a number of heretical popes in the past and of a female pope (which in Hus' version of the legend was called Agnes and came from England). ${ }^{9}$ How can such a scandalous church dare to claim holiness and obedience? Instead, the sancta et katholica ecclesia, which Christ called "his church" (Mt 16:16), is the congregation of the predestined. The Roman Church on the other hand may be called the congregation of the faithful of Christ that dwell under the obedience of the Roman bishop. As such it is not different from the church that dwell under the obedience of any other archbishop. Hus also rejected the particular meaning of ecclesia romana understood as just pope and cardinals. They form a collegium, but not a church. On account of his predestination ecclesiology, Hus protested sharply against the presumption that every faithful has to recognize the pope as head and that obedience to him is a necessary requirement for salvation. ${ }^{10}$

While Hus was risking increasingly a clash with church authorities, some of his supporters among the university professors in Prague took the distance to the radical opinions of their colleague. Stanislaus of Znoimo and Stephen Páleč were the center of this opposition. Still before the Faculty of Theology at the University of Prague issued a memorandum against Hus in February 1409, Stanislaus of Znoimo and Stephen Páleč had already published a number of treatises, in which they defended the Roman Church against the assaults of their colleague. Against those who derided the Roman Church Páleč replied that the Church in Bohemia believes and keeps whatever the Roman Church has believed and kept as Catholic truth. The sins of the higher clergy cannot annihilate the power they have received to lead the Church. For Páleč, conformity with the Roman Church was an important criterion to be part of the universal Church. ${ }^{11}$

Hus responded to his critics in part two of his treatise De ecclesia (cc. 11-23), in which he turned exclusively to the problem of church authority and of obedience to the pope (de potestate ecclesiae). Besides responding meticulously to the arguments of his opponents, this second part of the treatise refined Hus's understanding of church authority within the context of predestination ecclesiology. His comments lead to new reactions and responses from Páleč and Znoimo, among others. Eventually the king decided that both Hus and his fiercest enemies had to leave Prague. Now, the road to Constance, where the conflict escalated, was paved. The Council condemned Hus as a stubborn heretic and burnt him at the stake. Páleč, who had accused his old friend and supported the 
conciliar decision against him, became a persona non grata in Bohemia. So he preferred to go to Poland, while Stanislaus had already died on his way to Constance. ${ }^{12}$ While Hus' former colleagues decided to argue with their colleague, at least as long as possible, Gerson in his letter to the archbishop of Prague was much more impatient, bursting out, that such heresies had to be eradicated by fire and sword rather than tolerated by intellectual debate. Páleč and Znoimo preferred the more peaceful way of curiosa ratiocinatio, to use the dismissive formula of the Parisian chancellor.

Hus' criticism, especially his frontal attack on the Roman Church, motivated Znoimo and Páleč to broaden their understanding of papal authority and papal infallibility. So their response was not to draft lists of errors - a method that was the usual way to trace heresies among academics and would have called for immediate disciplinary action against Hus ${ }^{13}$ - but to argue with and against him by developing their own understanding of church. Besides rejecting Hus' predestination ecclesiology and the disciplinary consequences he draw from it, Znoimo and Páleč focused on the notion of ecclesia romana, examining its significance and importance. This seems remarkable for a a number of reasons. Instead of insisting on the primacy of the pope or on papal plenitude of power, the two Bohemian theologians elaborated the ecclesiological purpose and the nature of the Roman Church. First of all, they accepted Hus's definition of the Roman Church as consisting of pope and cardinals. Since the $12^{\text {th }}$ century, ecclesia romana had been interpreted by famous decretists also in terms of ecclesia universalis. ${ }^{14}$ Instead of going back to such conceptions, Znoimo and Páleč took up the narrow understanding of ecclesia romana that Hus bedeviled. They defended the Roman Church understood first of all as the pope together with his cardinals. Despite its small number, the "college" of pope and cardinals form one ecclesial entity. Znoimo called it a mysticum et ecclesiasticum compositum. Formally this compositum is identical with the college of Peter and the apostles, therefore it carries particular responsibility for the entire Church. The Roman Church as a mysticum compositum cannot forfeit the faith although neither the pope nor the cardinals are infallible as individual persons. On account of this privilege the Roman Church shares in the universal nature of the perfectus corpus Christi mysticum, which means that also the Roman Church enjoys a certain perfection. ${ }^{15}$

One might ask, why the two theologians maintained the perfection and holiness of the Roman Church despite the justified criticisms of Hus and despite the deplorable situation of a papacy unable to solve the Western Schism and even actively working against the common efforts to overcome the separation of the Church. The ongoing scandalous schism in particular raised questions about the reliability and the truth of the Church. Was there yet any certainty regarding the true pope and the true (Roman) Church after so many years of schism? Was there, consequently, still certainty about the reliability of salvation in the Church? Znoimo dismissed such doubts by reassuring the reader: Certum est quod in una parcium mundi est sedes Apostolica et Romana ecclesia. ${ }^{16}$ Despite the schism the authority of the Apostolic See was still necessary and the importance of the institution was unquestioned. For Znoimo, the Roman Church was the ultimate institution to grant certainty on dubious matters of faith. Such certainty could never be guaranteed by a presumed ecclesia iustorum, which would necessarily remain invisible and obscure. But the concept of ecclesia universalis was equally problematic to provide help in dubious questions of faith, since it was too big and amorphous a reality to be called into one place. Only the ecclesia romana was able to do so. Already in De aequivocatione nominis ecclesiae, his first treatise against Jan Hus, 
Stephen Páleč had distinguished six different realities of church, starting from church buildings, general councils, the ecclesia praedestinatorum, all the way down to the community of all the baptized and believers. Contrary to Jan Hus, Páleč emphasized the church that consisted of the praelati et maiores. Within this group he located the Roman Church as the church that has binding authority. ${ }^{17}$

\section{Basel $1432-1433$}

After Jan Hus' execution in Constance the situation in Bohemia escalated. National anger and frustrated reform zeal sparked off the Hussite revolution. ${ }^{18}$ Despite their differences the various reform groups in Bohemia found sufficient common ground to agree on the so-called four Prague articles: holy communion under both species, free preaching of the word of God, punishment of mortal sins, and abolishment of ecclesiastic possessions and dominion. These four demands shaped the reform agenda and the Hussite identity for the next decades. ${ }^{19}$ None of these articles did address ecclesiology or the nature of the Church or ecclesiastical power strictly speaking. This may surprise, given the fact that Hus was condemned also because of his ecclesiology. Nevertheless, each of the four articles presupposed a certain view of Church and each of them was defended by a number of ecclesiological arguments.

The most visible encounter between hussite and traditional catholic theology was to take place at the Council of Basel, prepared, however, by a large number of writings Contra hussitas. ${ }^{20}$ After military actions proved to be completely unsuccessful, representatives of the Church and the Empire sought for negotiations with the Hussites at the imminent Council of Basel. The difference between this synod in Basel and the one in Constance could not be greater. While the Council of Constance treated Hus as an obstinate heretic, eventually sentencing him to death, the Council of Basel was forced to welcome the Hussite party amicably as proud representatives of a large local church and a self-conscious nation. In preliminary negotiations at Cheb (Egra), the Hussites insisted that the ultimate "judge" in the upcoming disputation on the legitimacy of the four Prague articles had to be the lex Dei, i.e. the (written) word of God. So the disputation between the Hussites and the Fathers in the Council of Basel did not only reflect two different visions of Church, but also two different criteriologies of theology: The Hussites wanted to accept only arguments taken from the Bible and from the practice of the early Church (ecclesia primitiva). The representatives of the Council of Basel, on the other hand, emphasized the authority and actually the superiority of the universal council as the representation of the entire universal church. So the disputation in Basel was not so much about differences in the life of the Church rather than on the way of arguing in theology and in the priority of the Bible versus the Church or vice versa. ${ }^{21}$

Those who spoke on behalf of the Council ${ }^{22}$ had an enormous interest to raise fundamental questions of ecclesiology, certainly with the intention to "defeat" the Hussite delegation and to entice them back into the catholic Church, but also to demonstrate the superiority of conciliarism as the authentic and better theory of church after the trauma of the schism. Consequently, the four speakers of the Council of Basel, who had to argue each against one of the four Prague articles, led the discussion unflinchingly into basic ecclesiological matters, so that the entire disputation took on an enormous ecclesiological load. Consequently it served as a 
training field to sharpen the Council's ecclesiological convictions. Each of the four speakers would at some point emphasize the representation of the universal Church in the general council and discuss the council's infallibility as a consequence of the representation of the Church in and by the council. John of Ragusa OP, for instance, who opposed the first article on the required communion under both species, insisted on the Church's infallibility because it guaranteed the reliability and truth of ecclesiastical or liturgical rites. The Hussites, on the other hand, blamed the (Roman) Church for having betrayed the order and the legacy of the early church, when it altered the sacramental practice. Against such argumentation of historical discontinuity, Ragusa stressed the perpetuity of the Church's authority and its legitimate right to regulate and adapt the liturgical life according to the circumstances of the time. So, the occasion of discussing changing liturgical rites in the Church provided an occasion to introduce the topic of infallibility into the ecclesiological debates of the $15^{\text {th }}$ century. Infallibility in that context was not related to papal authority or papal magisterium. Instead, it addressed the problem of certainty and trust in the Church as a reliable institution, in which each believer could be confident to receive salvation. Henry Kalteisen $\mathrm{OP}$, who defended the church's preaching practice as to be ordered hierarchically by episcopal power, addressed the infallibility of church and council as well. Taking up Hus's criticism that unholy clergy cannot claim ecclesiastical authority, he developed an argument for the infallibility of universal councils. ${ }^{23} \mathrm{He}$ admitted that universal councils are not, of course, gatherings of exclusively holy people. Usually, there are many among the Fathers who do not lead an exemplary life. Nevertheless, taken jointly all the members of a universal council, when gathered at one place, would enjoy collegial infallibility. The Holy Spirit would vouch for their decisions as long as they abide by the conciliar rules. Comparable to a sacrament, which confers grace upon the recipient as long as the rite is performed correctly and legitimately, the decrees of a general council would be infallible as long as the council is celebrated canonically, irrespective of the personal holiness of the members of the council. ${ }^{24}$

15 The Hussites protested sharply against the repeated ecclesiological digressions of their opponents. In their eyes, the four articles of Prague presented a serious reform project. However, they were not meant to engage in fundamental debates about the nature of the Church because this would distract from the real issues at stake. Moreover, they were suspicious about the council's claims to be recognized as the highest, infallible authority in the Church. Such recognition could easily turn against themselves, giving up their strategic position and betraying Jan Hus's legacy, which had been condemned by a general council. Indeed, most of the Fathers at the Council of Basel stressed the role of the universal council as the highest court yard of the Church (supremum tribunal). On the backdrop of Hus' fate, however, there was no way for the Hussites to accept an agreement regarding conciliar authority.

Like the earlier controversy between Jan Hus and his colleagues in Prague, the Council of Basel too pushed the doctrinal development of ecclesiology ahead. The same John of Ragusa, who defended the catholic practice of communion against the Hussite request for the chalice, composed a lengthy Tractatus de ecclesia shortly after the Hussites had left the council in the spring of 1433. In this work he summarized the ideas on the Church that occurred to him during the discussion with Jan Rokycana, his Hussite opponent. ${ }^{25}$ Werner Krämer called this text the first treatise of modern catholic ecclesiology. ${ }^{26}$ I would be more cautious using such labels, since the discussion 
regarding the nature of the Church began much earlier, as we have pointed out above. Ragusa's treatise relied on earlier anti-hussite literature as well as on intensive discussions among the experts in Basel. Ragusa's work is nevertheless remarkable, since he widely abstained from polemics that permeated most ecclesiological literature at his time. He understood that Hussitism along with the ongoing debates in Basel on the authority of Church, pope and council required a deliberate and coherent presentation of the Church.

17 Ragusa's central question was: "Who is the true church and where can it be found?" It was the same question that spiritualist movements since the poverty controversy of the $14^{\text {th }}$ century posed in order to criticize the papal church. It was also the question that Hus asked in his De ecclesia, where he found an answer in predestination ecclesiology. Ragusa clearly ruled out that solution. The eccelsia praedestinatorum cannot represent the true Church, since predestination does not create a quality in a believer. Predestination is simply a relation in God's mind, it is not a subjective criterium of church membership in the soul of a believer. Such criteria would be faith, or love, or a baptismal character, features for which someone has to opt and make a decision. Accordingly, Ragusa defined the universal Church as "the congregation of the faithful that are united to Christ by faith, hope and love". He further distinguished a "material" and a "formal" understanding of that definition. The Church materialiter taken consists of all the faithful spread around the world. Under a formal aspect, however, the universitas fidelium is fully present in the universal council, which may to be called rightly ecclesia universalis. ${ }^{27}$ So Ragusa's intentions in writing his treatise went beyond simply criticizing Hus' predestination ecclesiology. Instead, he was at the same time looking for a proper place of the universal council within an ecclesiology that needed to be conceived in strictly theological terms.

Ragusa furthermore dedicated a large section to the understanding and significance of the ecclesia romana. This came certainly as a reaction against the vilification of pope and cardinals in Hus' ecclesiology. Modern scholars were wondering why Ragusa, an otherwise staunch conciliarist, would defend the papacy, and the pope, who was so bitterly opposed to the claims of the Basel synod and sedulously tried to dissolve it. These scholars spoke about a war on two fronts that the fathers in Basel had to wage: one against the disputed validity of ecclesiastic authority in general in Hus' predestination ecclesiology, the other against the uncompromising concentration of ecclesiastical power in a single papal monarch. There is certainly some truth in this observation. For the theologians in Basel, the papacy was part of the apostolic constitution of the Church, which cannot be abolished or radically transformed without destroying the traditional order. More important in my opinion, however, was the particular understanding of ecclesia romana for Ragusa and other conciliarists. The Roman Church represented that aspect of the universal Church that received Christ's promise to remain uncompromised and unaffected by error until the end of the world. The ecclesia romana, in other words, referred to the indefectible reality of the Church; it was a synonym of the Church's steadfastness in faith. The Decretum Gratiani collected a number of texts from the early Middle Ages, which documented the privilege of indefectibility of the Roman Church. ${ }^{28}$ For this reason the meaning and significance of eccelsia romana was a matter of intensive discussion in the late medieval period. Jan Hus' criticism of the Roman Church was not simply a sarcastic complaint about scandal popes and cardinals, but a serious challenge of the Church's authority and infallibility. In the end it jeopardized the nature of the Church. Consequently Ragusa demonstrated 
that the Roman Church was not just the church of the pope and the cardinals, a reality, he described as the "material" aspect of ecclesia romana. Instead by ecclesia romana one has to understand that aspect of the entire universal church that remains in contact to and in continuity with the apostle Peter, who professed the true and reliable faith. The formal aspect of ecclesia romana would then be the universal council, insofar it shares in the Petrine promise of infallibility and indefectibility. ${ }^{29}$

In the second part of his treatise, Ragusa chose the four notae ecclesiae (unity, sanctity, catholicity, apostolicity) to further map out his ecclesiology. In this part he conceived of the Church as the body of Christ, with each nota highlighting a particular relation between the faithful and the mystical body of Christ. An ecclesiology according to these four characteristics of the Church had been outlined also in a sermon by Thomas Aquinas. The Augustinian Hermite Jacobus de Viterbo took the same Thomistic schema for his treatise on ecclesiastical authority, written in the early $14^{\text {th }}$ century. ${ }^{30}$ The struggles on authority in and over the Church in the $14^{\text {th }}$ and $15^{\text {th }}$ left little room for such fundamental ecclesiology. So it was indeed Johannes de Ragusa who retrieved this structure for a basically theological consideration of the Church. After him, it was his confrère Johannes de Turrecremata OP, who resumed this pattern in his Summa de Ecclesia. Torquemada's Summa became one of the most influential ecclesiological works for the modern period, while Ragusa's treatise survived undiscovered and unnoticed in only two manuscripts until the $20^{\text {th }}$ century, when conciliar ecclesiology experienced its great revival. ${ }^{31}$

Basel had to treat the Hussites politely because of the treaty of Cheb, which prohibited any hostile action against each other. Still many council fathers were convinced that the Hussites were heretics, not deserving any patience or tolerance. So they tried to trap them. At the end of the first round of speeches, the president of the Council Cardinal Giuliano Cesarini confronted them with a number of heretical Wyclifite teachings, doctrines that were taken from the 45 articles condemned at the Council of Constance, which the Hussites allegedly mentioned in their speeches. For the sake of clarity Cesarini prompted the Hussites to abjure or to acknowledge these doctrines. ${ }^{32}$ of course, the Hussites saw through this tactic and evaded an answer by postponing and protracting the issue. In the end, Basel did not condemn the Hussites, but succeeded to negotiate a peace treaty on a middle-ground, that conceded the Hussites to keep some of their particular rights, while acknowledging the authority of the Roman Church. The so-called Compacts of Iglau and Prague could not provide a basis for a lasting agreement between Rome and Bohemia, but it would be unjust to simply dismiss them as a rotten compromise. Obviously, a different attitude was required to reconcile an entire regional church and a nation rather than insisting on uncompromising demands. Part of this new approach was the openness to resolve differences by intensive theological debate. Instead of just another condemnation of heretical articles the Council of Basel left as its legacy eight monumental speeches, composed by common conciliar efforts and arguing against each other on certain reform issues, but mostly on a different view of church. Ratiocinatio won over fire and sword. However, the "reasoning" that Gerson warned against did little to convince either the Hussites or the catholics. But it provided an important occasion for each side - certainly for the catholic party - to broaden its own self understanding by a refined and argumentatively expanded ecclesiology. This new ecclesiology represented by Ragusa and others mirror the challenges of Hussite ecclesiology. In other words, the theology of the Church on the threshold to the modern period came about as a 
blueprint of Wyclifite and Hussite ecclesiology. Predestination ecclesiology was not rejected altogether, but received its correction and integration into a refined traditional form of ecclesiology. This traditional ecclesiology relied on the most important ecclesiological model, the body of Christ metaphor. It was also flexible enough to integrate the challenges and the aspirations of conciliarism. This leads us to the third and final part of our paper.

\section{Rome 1450 - 1453}

The major contribution of the Council of Basel for the development of catholic ecclesiology awaits still a major and adequate appreciation. ${ }^{33}$ For a long time, the council's image was overshadowed by a defamatory view of the council as of a cohort of troublemakers, a bunch of lower clergy and irresponsible, over-ambitious people, who steered the Church into a new schism and tried to substitute the monarchical constitution of the church by some form of conciliar oligarchy. To this end, the Council of Basel declared Pope Eugenius a heretic, deposed him and elected another pope. Eugenius IV, however, was able to resist this attack on papal authority and in turn condemned the Council of Basel and the radical conciliarists who worked hard to subvert the constitution of the Church. This was the curialist "Roman" narrative of the events, which succeeded to dominate the text books in the past. Part of Eugenius' victory was owed to the successful handling of the Council of Ferrara-Florence, where a union with the Greek Church confirmed the role and prerogatives of the papacy. After Eugenius had condemned the Basel conciliarists as heretics and schismatics and had sought sufficient support form the princes, his successors could consolidate the Church by pro-actively ignoring conciliarism and staging a revival of papalism both literally, artistically and theologically. But this is would be a different story.

More interesting for our purpose are the critical months between 1438 and 1440, when pope and council accused themselves mutually of heresy and when the fierce fight about superiority in the Church entered its last round. The situation became very tense when the Council of Basel reinforced the decree Haec sancta of the Council of Constance, declaring this decree not just a commonly held doctrine or conviction, but a truth of catholic faith. The respective decree, the so-called tres veritates, issued on May 16, 1439, declared the stipulations of Haec sancta a dogma of the Church, which obliged a pope to respect the "truth" about the universal councils and called upon him to obey its commands. The third "truth" stated explicitly: "Whoever contradicts the two aforementioned truths (regarding the authority of the universal council) has to be considered a heretic." Pope Eugenius in turn condemned the tres veritates as an erroneous interpretation of Haec sancta and declared the fathers in Basel as heretics and schismatics. ${ }^{34}$ So the controversy about the constitution of the Church and the legitimate share of power and authority in its representatives and institutions ended in a fiasco. Both sides accused one another of having an erroneous understanding of the faith, of the faith regarding the constitution and the power of the Church to be precise. While the conciliarists considered the decree Haec sancta as their doctrinal foundation, the pope and his supporters insisted that Haec sancta was not applicable in this case. In their opinion, Haec sancta needed to be interpreted according to an older tradition that acknowledged the Apostolic See as the highest authority in the Church without any exceptions. Both positions had some good arguments on their sides, and both were 
convinced to solve the differences by plausible reasons and theological debate. However, the actions that both sides had initiated left only little middle-ground. The quest for superiority required a clear cut answer, no careful pondering. Nevertheless, the Tres veritates were object of frantic theological consideration. On part of the conciliarists, John of Segovia composed a lengthy commentary on the decree, his Explanatio de tribus veritatibus fidei. ${ }^{35}$ Besides Segovia a number of representatives of the Council defended their decisions at diets and the courts of secular princes. This diplomatic engagement produced an impressive amount of ecclesiological literature. ${ }^{36}$ For the papal side, the Dominican John de Torquemada rejected the Tres vertiates during a public disputation at the Council of Ferrara/Florence. This Oratio synodalis was one of the most famous rejections of conciliarism; its arguments became common place among the growing number of defenders of papalism. ${ }^{37}$

Despite the noisy mutual condemnations, the issue was more complicated. Conciliarism was a new phenomenon and was considered by many a legitimate interpretation of Church government. "Papalism" on the other hand has never been condemned either. So no side could rely on earlier condemnations in order to substantiate their own claims. The supposed "heresies" were rather novel; in part they were declared heretic only on account of contemporary or recent legislation. Never had conciliarism been formally condemned (because it did not exist in the way the Basel fathers practiced and conceived of it), nor had papalism been ever condemned as a blatant disregard of conciliar authority. A solution of the heated debated needed to be found by means of scholastic controversial theology which included a coherent historical documentation and a set of plausible arguments from the field of canon law, political philosophy and biblical exegesis.

24 Some years after the Council of Basel had been put to a rest by Pope Nicholas V, the Dominican Juan de Torquemada, one of the staunchest defenders of the papal rights at the Council of Basel, composed his ecclesiological synthesis, the Summa de ecclesia. The work was finished in 1453. ${ }^{38}$ Like Ragusa's Tractatus de ecclesia, Torquemada's Summa can be read as a mirror, a commentary or a blueprint of the ecclesiological controversies in Basel that fought for a correct understanding of the nature of the Church and for a correct and matching form of church government. Like Ragusa's and Hus' treatises on the Church, Torquemada's Summa too marks the beginning of modern catholic ecclesiology. The tone is more accademic, deliberative and technical. Only rarely did Torquemada polemize against actions and attitudes he witnessed at Basel or elsewhere. The main purpose of the work was to provide a comprehensive if not exhaustive presentation and doctrine of the Church, which is guided by the successor of Peter. ${ }^{39}$

Torquemada structured his Summa in three parts (books). In the first part he addressed the theological nature of the Church. He started with a terminological clarification, but he quickly moved on to the explanation of the main ecclesiological metaphor, the corpus Christi mysticum. Within this section - largely influenced by thomistic theology of grace - Torquemada rejected Hussite predestination theology as well as the artificial division of the church into a political corporation and a pneumatical organism through which God communicates grace.

Remember that Hus gave three different meanings of Church in his De ecclesia, Stephan Páleč and Johannes de Ragusa added another three. Torquemada, aware of the foregoing deliberations, listed a total of 16 different uses of the word ecclesia. ${ }^{40}$ Against 
the Hussite doctrine he defined the Church as the collectio catholicorum or the universitas fidelium living in this world. Reasoning about the Church and its members according to their future, eternal status is beyond the power of our intellect, since only God knows the number of the elect who will join him in eternal beatitude. ${ }^{41}$ After Torquemada had clarified the terminology, definition and subject matter of his ecclesiology, he went on to describe the Church according to the four notae ecclesiae: one, holy, catholic and apostolic. ${ }^{42}$ After a short consideration of the inception of the Church and its duration, he explained the many biblical metaphors of the Church ${ }^{43}$, insisting mostly, however, on the main metaphor, the "body of Christ". By way of this model, the Church appears as the particular "space", in which Christ, the head, relates to his members and is connected with the faithful in various degrees of intensity. ${ }^{44}$ The two final parts of the first book introduced the various status and offices in the Church: bishops, cardinals and priests ${ }^{45}$, before he explained the twofold ecclesiastical power, sacramental and disciplinary. ${ }^{46}$

The second book, the longest of the entire work, is devoted exclusively to the pope. Besides offering a profound and complete discussions of the papal office, this second book zoomes in on all the difficulties that the papacy had experienced since the beginning of the Great Schism. After the long second book on pope and papacy, Torquemada wrote a third book to rehearse the forms, the role and the authority of councils in the Church. This third book contains countless references to the Councils of Constance and Basel, often times personal memories of the author, who was not sparing with criticism, occasionally, however, also applause. ${ }^{47}$ Many people at the time and many scholars up to this day considered Torquemada as one of the most loyal defenders of the papacy during the heated days of the Council of Basel. At a closer look, however, Torquemada set out a carefully balanced ecclesiology, keeping many ideas of the conciliar reform movement alive and supporting modest, but important measures of control of the papal government. ${ }^{48}$ Hence, his Summa de Ecclesia would be another example for our assumption, that controversies on the nature, life and constitution of the church enriched the ecclesiological discussion of the day, particularly if that discussion was led by mindful observers, who recognized the legitimate concerns in the otherwise radical protests against the Church and its institutions.

Torquemada concluded his Summa by a shorter fourth book, consisting of two parts, the first of which dealing with schisms and schismatics, the second with heresies and heretics. One could discover in this final part - which, by the way, offers an elaborated heresiology - the deeply rooted distrust of the typical Dominican inquisitor. This, however, would be a weak explanation for Torquemada's interests in these topics, and it would completely miss the point. For Torquemada, schisms and heresiology were constitutive parts of ecclesiology. Ecclesiology had (and has) to take into account the ideas and criteria that threaten the unity of the Church and the integrity of its faith. For Torquemada, a schismatic was someone who destroys the unity of the Church, but he was not necessarily a heretic. Every heretic, however, was - at least in Torquemada's opinion - a schismatic, since his wrong beliefs about one or more articles of the faith would entail a separation from the Church as the congregation of the faithful. ${ }^{49}$ Schism and heresy are the flip side of ecclesiology, not just a part of it. In other words, the Church defines herself by identifying the margins of the catholic faith and testing the limits of her tolerance. It would require another paper to present Torquemada's emphases in his heresiology. Just two short remarks may suffice: First, it is remarkable, how closely Torquemada leaned on the notion of faith as developed in Thomas Aquinas' 
theology. Second, Torquemada spent considerable effort to define the notion of "catholic truth" (catholica veritas) as the intellectual bar that separates doctrine (or behavior) from becoming a heresy.

Let me conclude by a reflection of Torquemada why God would allow so many heresies to inflict the Church, since he promised to guide his Church and to be with her until the end of time. ${ }^{50}$ Torquemada reminded the readers that God usually permits evil only to effect a good or to bring about something better. So heresies have ultimately a positive effect for the Church despite the damage they create. Torquemada identified six such benefits for the Church: First, heresies have the potential to elucidate the truth of the faith more brightly. Second, heresies spur the lazy catholic doctors of theology to be more vigilant and to stand up against the enemies of the faith. The third reason is related to the second: Heresies increase the wisdom and knowledge of the catholic professors (doctores ecclesiae). Fourth, heresies test the patience of the faithful, since heretics tend to be arrogant. Fifth, by opposing the heresies, catholic teachers earn merits for the eternal life. And sixth, the identification of heresies reveals the steadiness of faith in many righteous catholics, whose qualities would otherwise have remained hidden. I think that the third reason was most dear to Torquemada: Heresies ultimately advance and refine theology. Therefore, heresies belong to ecclesiology in the same way as errors, that are identified as such, advance the the search for the truth. Such method, however, was intrinsically medieval and scholastic. ${ }^{51}$

\section{NOTES}

1. The correspondence between Conrad of Vechta and Jean Gerson is documented in S. HARRISON THOMson (éd.) Magistri Joannis Hus, Tractatus de Ecclesia, Cambridge 1956, xviii-xix. On the trial of Jan Hus in Constance see : K. HRUZA, «Die Verbrennung von Jan Hus auf dem Konstanzer Konzil 1415 », in G. SCHEIBELREITER (éd.) Höhepunkte des Mittelalters, Darmstadt 2004, p. 202-220 ; F. SEIBT, «Hus in Konstanz », in Annuarium Historiae Conciliorum 15 (1983), p. 159-171 [reprint in IDEM, Hussitenstudien, München 1987, p. 229-240] ; W. BRANDMÜLLER, « Hus vor dem Konzil », in F. SEIBT (éd.), Jan Hus. Zwischen Zeiten, Völkern, Konfessionen, München 1997, p. 235-242. The trial is also abundantly documented in the monographical literature on Jan Hus: P. HILSCH, Johannes Hus. Prediger Gottes und Ketzer, Regensburg 1999; E. WERNER, Jan Hus. Welt und Umwelt eines Prager Frühreformators (Forschungen zur mittelalterlichen Geschichte 34), Weimar 1991; Th. A. FUDGE, Jan Hus : Religious Reform and Social Revolution in Bohemia, Londres, 2010.

2. On the ecclesiology of Gerson and Hus, see : J. LOSERTH, Hus und Wiclif, München 1925 ; P. DE vooGHT, L'hérésie de Jean Huss, Louvain 1960 ; Id., Hussiana, Löwen 1960 ; M. sPINKA, John Hus' Concept of the Church, Princeton 1966; P. DE VooGHT, L'hérésie de Jean Huss (Bibliothèque de la Revue d'histoire ecclésiastique 34) Louvain 1960 ( $2^{\text {nd }}$ ed. 1975); A. PATSCHOFSKY, "Ekklesiologie bei Johannes Hus", in H. BOOCKMANN, B. MOELLER, K. STACKMANN (eds.), Lebenslehren und Weltentwürfe im Übergang vom Mittelalter zur Neuzeit (Abhandlungen der Akademie der Wissenschaften in Göttingen, Phil.-hist. Klasse, Folge 179), Göttingen 1989, p. 370-399 ; F. J. HOLEČEK, « Hussens Kirchenverständnis ", in SEIBT (ed.), Jan Hus - zwischen Zeiten, Völkern, Konfessionen, München 1997, p. 183-191 ; W. R. cooK, « John Wyclif and Hussite Theology, 1415-1436 », in Church History 42 (1973) 
335-349. - On the ecclesiology of Jean Gerson see : L. PASCOE, Jean Gerson : Principles of Church Reform, Leiden 1973; G. H. M. Posthumus MEYJES, Jean Gerson - Apostle of Unity: His Church Politics and Ecclesiology, Leiden 1999 ; D. ZACH FLANAGIN, « Making Sense of It All : Gerson's Biblical Theology », in B. P. McGuiRe (ed.), A Companion to Jean Gerson, Leiden 2006, p. 133-177.

3. «Ecclesia autem sancta katholica, id est universalis, est omnium predestinatorum universitas, que est omnes predestinati presentes, preteriti et futuri ", Johannes Hus, De ecclesia, c. 1, THOMSON (ed.), (see fn 1), 2. A similar definition occurs at the end of De ecclesia, ch. 1, THOMson (ed.), 7.

4. Cf. E. SELLEY MOLNAR, "Wyclif, Hus and the problem of Authority ", in SEIBT, Jan Hus - Zwischen Zeiten, Völkern, Nationen (fn 1), p. 167-182.

5. Predestination was nevertheless part of ecclesiology also in earlier authors. The traditional corpus Christi model discussed the relationship of each human being to Christ in terms of grace, be it actual or potential, by various degrees of faith, or in view of eternal predestination of rejection. Se for instance THOMAS AQUINAS, Summa Theologiae, III, qu. 8 ( (On the headship of Christ »).

6. Cf. A. BRUNGS, Fr. GOUBIER, "On Biblical Logicism: Wyclif, virtus sermonis and equivocation ", in Recherches de Théologie et Philosophie Médiévales 76 (2009), p. 199-244; T. S HOGIMEN, "John Wyclif's Ecclesiology and Political Thought », in I. C. LEVY (ed.), a Companion to John Wyclif, Late Medieval Theologian, Leiden 2006, p. 199-240.

7. Cf. Hus, De ecclesia, ch. 7 (« on the Roman Church »).

8. Cf. HUS, De ecclesia, c. 4 ; ed. Thomson 20. «... nullus prescitus est membrum, sancte matris ecclesie katholice. ", ibid. 23.

9. M. KERNER, K. HERBERS, Die Päpstin Johanna : Biographie einer Legende, Köln, Wien 2010.

10. Hus, De ecclesia, c. 7, ed. Thomson 49f.: In this passage Hus also criticized the Donation of Constantine as the reason for the papal presumption and pomp.

11. S. PÁlEč, Antihus, ed. Sedlák, in Miscellanea hussitica Ioannis Sedlák, Prague 1996, p. 366-507, here p. 369. - On Páleč see: A. FRENKEN, «Páleč, Stephan ", in Biographisch-bibliographisches Kirchenlexikon VI (1993), p. 1453-1456; J. N echutovÁ, M. Štepán von Páleč und die HusHistoriographe, in Mediaevalia Bohemica 3 (1970), p. 87-122 ; J. HRDLIČKA, « Hus und Páleč », in SEIBT (ed.) Jan Hus - Zwischen Zeiten, Völkern, Konfessionen (fn 2), p. 103-106.

12. The details of the literary and theological battle that lead to Hus's execution are listed in J. KADLEC, "Das Hussitentum und die Prager Theologieprofessoren", in Renovatio et reformatio. Wider das Bild vom 'finsteren' Mittelalter. Festschrift für Ludwig Hödl zum 60. Geburtstag, ed. by M. GERWING and G. RUPPERT, Münster 1985, p. 224-234 ; P. DE VOOGHT, «L'ecclésiologie catholique autour de 1400 », in Id., Hussiana, Louvain 1960 (reprint 1975), p. 102-160.

13. J. MIETHKE, Gelehrte Ketzerei und kirchliche Disziplinierung. Die Verfahren gegen theologische Irrlehren im Zeitalter der scholastischen Wissenschaft, in: Recht und Verfassung im Übergang vom Mittelalter zur Neuzeit, II. Teil, éd. H. BOOCKMANN, L. GRENZMANN, B. MOELLER, M. STAEHELIN (Abh. der Akademie der Wissenschaften zu Göttingen, Phil.-hist. Kl., III.239), Göttingen 2001, p. 9-45; W. J. COURTENAY, The Preservation and Dissemination of Academic Condemnations at the University of Paris in the Middle Ages, in Les Philosophies morales et politiques au Moyen Âge / Moral and Political Philosophies in the Middle Ages. Proceedings of the $9^{\text {th }}$ Internat. Congr. of Medieval Philosophy, Ottawa, 1992 ; C. BAZÁN, E. ANDÚJAR, L. SBROCCHI (eds.), New York-Ottawa-Toronto 1995, Bd. III, 1659-1667 ; IDEM, Papal Policy on Judging the Orthodoxy of University Masters, A Research Problem, in Knowledge, Discipline, and Power in the Middle Ages, Essays in Honouur of David E. Luscombe, J.CANNING, E. KING, M. STAUB (eds.), Leiden-Boston 2011, p.157-173 ; U. KÖPF, Die Ausübung kirchlicher Lehrgewalt im 13. und 14. Jahrhundert, in Gewalt und ihre Legitimation im Mittelalter, G. MENSCHING (éd.), Würzburg 2003, p. 138-155; 
14. B. TIERNEY, Foundations of the Conciliar Theory. The Contribution of the Medieval Canonists from Gratian to the Great Schism, Cambridge 1955 ( $\left.{ }^{3} 1968\right)$, 36-46, 149-143; Y. CONGAR, Ecclesia Romana, in Cristianesimo nella Storia 5 (1984), p. 225-244.

15. S. DE ZNOIMO, Tractatus de Romana ecclesia, J. SEDLÁK (éd.), in Miscellanea hussitica Ioannis Sedlák, Prag 1996, p. 312-322, here especially p. 313-316. - With regard to the purpose and the mission of the Church as such, Znoimo specified that both the universal Church and the Roman Church have to spread the faith on earth and to continue Christ's mission in this world.

16. Ibid. p. 317.

17. S. DE PÁLEČ, De aequivocatione nominis ecclesie, J. SEDLÁK (éd.), in Miscellanea hussitica Ioannis Sedlák, Prag 1996, p. 356-363. - Páleč substantiated his point by listing a number of privileges of the Roman Church, which he found documented in the Decretum Gratiani. See also fn 28, here below.

18. The magisterial work on the Hussite revolution is F. ŠMAHEL, Die hussitische Revolution, 3 vols. (MGH-Schriften 43/I-III), Hannover 2002 ; H. KAMINSY, A History of the Hussite Revolution, Berkeley 1967 (reprint Eugene, OR 2004) ; F. SEIBT, « Die hussitische Revolution », in Id., Hussitenstudien, München 1987, p. 79-96.

19. F. ŠMAHEL : "Die vier Prager Artikel. Das Programm der hussitischen Reformation », in W. EBERHARD, F. MACHILEK (eds.), Kirchliche Reformimpulse des 14./15. Jahrhunderts in Ostmitteleuropa (Forschungen und Quellen zur Kirchen- und Kulturgeschichte Ostdeutschlands, 36), Köln/Wien 2006, p. 329-340 ; K. MALÝ, "Die Bibel und das hussitische Rechtsdenken in den vier Prager Artikeln », in SEIBT (ed.), Jan Hus - Zwishcen Zeiten, Völkern, Konfessionen (fn 2), p. 227-234.

20. See the online database Repertorium operum antihussitorum collected by Pavel Soukup at www.antihus.eu.

21. On the "Judge of Egra " see: Amadeo Molnár, Chebský soudce (= The Judge of Egra), Cheb 1982 ; J. JIRKA (ed.), Soudce smluvený v Chebu, Cheb 1982 [= Conference Proceedings on the «Egra Judge »). - On the disputation of the four articles at the Council of Basel see : P. DE VOOGHT, « La confrontation des thèses hussites et romaines au concile de Bâle (janvier-avril 1433) ", in Recherches de théologie ancienne et médiévale 37 (1970) p. 97-137, p. 254-291; E. FRASER JACOB, « The Bohemians at the Council of Basel 1433 ", in R. W. SETON-WATSON (éd.), Prague Essays, Oxford 1949, p. 81-123.

22. Both the Council and the Hussites selected four speakers, who prepared themselves to defend or to argue against the four articles. On part of the Council, the pratice of holy communion was defended by John of Ragusa, OP, the penitential practice was defended by Giles Charlier, the practice of preaching under the jurisdiction of bishops was defended by Henry Kalteisen OP, the the right of the clergy to have possessions and dominium was defended by Juan de Palomar. On the Bohemian's side the speaker were: Johannes Rokycana for the chalice, Nicholas Biskupec for the article of the punishment of deadly sins, Ulrich of Znoimo to defend the « free preaching " of the word of God, and Peter Payne to defend the article on the poverty of the clergy.

23. See Th. PRÜGL, Die Ekklesiologie Heinrich Kalteisens OP in der Auseinandersetzung mit dem Basler Konziliarismus, Paderborn 1995, p. 76-80.

24. Hermann Josef Sieben was the first to compare such understanding of infallibility to the ex opere operato idea in sacramental theology Cluny, Paris, Saint-Martin-des-Champs, culte marial, chapelle de l'infirmerie: H. J. SIEBEN, Traktate und Theorien zum Konzil. Vom Beginn des Großen Schismas bis zum Vorabend der Reformation (1378-1521) (FThS 30), Frankfurt a. M. 1983, p. 173-175.

25. Scholars who examined Ragusa's work and thought found that large parts of the Tractatus de ecclesia resumed text from Ragusa's second replica against Rokycana. Ragusa's entire ecclesiology developed as an apology of the Catholic Church against the spiritual and remnant ecclesiologies of Wycliff and Hus. Cf. S. MADRIGAL, La Eclesiologia de Juan de Ragusa O. P. (1390/95-1443). Estudio e 
interpretación de su Tractatus de Ecclesia, Madrid 1995 ; Id., " Eucaristía e Iglesia en la 'Oratio de comunione sub utraque specie' de Juan de Ragusa ", in Revista Española de Teologia 53 (1993), p. 145-208, p. 285-340; P. VRANKIć, «Die Grundzüge der Konzilstheologie des Johannes von Ragusa ", in Annuarium Historiae Conciliorum 30 (1998), p. 287-310 ; Z. STRIKA, Johannes von Ragusa (†1443). Kirchen- und Konzilsbegriff in der Auseinandersetzung mit den Hussiten und Eugen IV., Augsburg 2000 ; Th. PRÜGL, « Modelle konziliarer Kontroverstheologie : Johannes de Ragusa OP und Juan de Torquemada OP auf dem Basler Konzil», in Die Konzilien von Pisa (1409), Konstanz (1414-1418) und Basel (1431-1449). Institutionen und Personen (Forschungen und Vorträge 67), J. HELMRATH u. H. MÜLLER (ed.), Ostfildern 2007, p. 257-287.

26. W. KRÄMER, Konsens und Rezeption. Verfassungsprinzipien der Kirche im Basler Konziliarismus (Beiträge zur Geschichte der Philosophie und Theologie im Mittelalter, neue Folge 19), Münster 1980, p. 182-206 (= « Die sukzessive Hinwendung des Johannes von Ragusa zur Konzilsidee »).

27. JOHANNES STOJKović DE RAGUSA, Tractatus de ecclesia. F. šAnjeK (ed.) (Croatica christiana. Fontes 1), Zagreb 1983, p. 13-15.

28. See in particular the canones in Decretum Gratiani, di. 21 and 22, as well as C. 24, qu. 1. Cf. B. TIERNEY, Foundations of the Conciliar Theory. The Contribution of the Medieval Canonists from Gratian to the Great Schism ( $1^{\text {st }}$ ed. Cambridge 1955), Leiden 1998, p. 36-46, p. 149-153.

29. RAGUSA, Tractatus de Ecclesia, ed. Šanjek $17 \mathrm{ff}$.

30. JAMES OF VITERBO, De regimine christiano. A critical edition and translation, R. W. DYSON (éd.), Leiden 1995.

31. In the third and final part of the Tractatus de ecclesia Ragusa returned to some controversial issues regarding the papacy and church authority. For this final part, Ragusa recycled much of his second reply against Jan Rokycana.

32. Se the account and the list of errors in Juan de Segovia's history of the council : Monumenta Conciliorum Generalium saeculi decimi quinti, vol. II, Vienna 1873, p. 320-322.

33. For a nuanced look at the Council of Basel see: J. HELMRATH, Das Basler Konzil 1431-1449. Forschungsstand und Probleme, Köln/Wien 1987; J. woHLMUT, «Die Konzilien von Konstanz und Basel », in G. ALBERIGo (éd.), Geschichte der Konzilien, Düsseldorf 1993, p. 235-290. (See also the Italian original : Storia dei Concili Ecumenici, Brescia, 1990); M. DECALuWE, A Successful Defeat. Eugen IV's Struggle with the Council of Basel for Ultimate Authority in the Church, 1431-1449 (Institut Historique Belge de Rome, Bibliothèque / Belgisch Historisch Instituut te Rome, Bibliotheek ; 59), Bruxelles/Roma 2009. - On the ecclesiologies of the council of Basel see : KRÄMER, Konsens und Rezeption (fn 23) ; A. BLACK, Monarchy and Community. Political Ideas in the Later Conciliar Controversy 1430-1450, Cambridge 1970; Idem, Council and Commune. The conciliar movement and the fifteenthcentury heritage, London 1979 ; J. woHLMUT, «Zur Ekklesiologie des Basler Konzils (1431-1449) im Streit um Reform und Autorität ", in S. WLODEK (ed.), Société et Église. Textes et discussions dans les Universités d'Europe Centrale pendant le Moyen Âge tardif, Turnhout 1995, p. 21-43.

34. The Tres veritates in : Mansi 29, 127 f. - The Bull Moyses vir Dei (4 sept. 1439) in : Conciliorum oecumenicorum decreta, p. 529-534.

35. J. D. MANN, The Historian and the Truths: Juan de Segovia's Explanatio de tribus veritatibus fidei. A Dissertation submitted to the Faculty of the Divinity School in candidacy for the degree of Doctor of Philosophy (Chicago, Ill., Jun 1993) ; the edition is on pp. 287-565 (= Appendix A).

36. See e.g. J. W. STIEBER, Pope Eugenius IV, the Council of Basel and the Secular and Ecclesiastical Authorities in the Empire. The Conflict over Supreme Authority and Power in the Church, Leiden 1978.

37. JOHANNES DE TURRECREMATA, Oratio synodalis de primatu, ed. Emmanuel Candal (Concilium Florentinum, B, IV/2), Roma 1954.

38. For the editions see: Th. KAEPPELI, Scriptores Ordinis Praedicatorum Medii Aevi, Rome 1980, vol. 3, p. 37 no. 2730 . 
39. On Torquemada's ecclesiology see: Th. M. IZBICKI, Protector of the Faith. Cardinal Johannes de Turrecremata and the Defense of the Institutional Church, Washington, 1981; K. BINDER, Wesen und Eigenschaften der Kirche bei Kardinal Juan de Torquemada O.P., Innsbruck 1955.

40. TURRECREMATA, Summa de ecclesia I, p. 2.

41. TURRECREMATA, Summa de ecclesia I, p. 3.

42. TURRECREMATA, Summa de ecclesia I, p. 6-21.

43. TURRECREMATA, Summa de ecclesia I, p. 31-42.

44. TURRECREMATA, Summa de ecclesia I, p. 43-68.

45. TURRECREMATA, Summa de ecclesia I, p. 69-86.

46. TURRECREMATA, SUmma de ecclesia I, p. 87-101.

47. A close account and examination of the third book of the Summa de ecclesia is provided by K. BINDER, Konzilsgedanken bei Kardinal Juan de Torquemada O.P., Wien 1976.

48. U. HORST, «Grenzen der päpstlichen Autorität. Konziliare Elemente in der Ekklesiologie des Johannes Torquemada », in Freiburger Zeitschrift für Theologie und Philosophie 19 (1972), p. 361-388 ; Id., "Kardinal Juan de Torquemada und die Lehrautorität des Papstes », in Annuarium Historiae Conciliorum 36 (2004), p. 389-422.

49. The respective definitions of schisma/schismatics and heresy/heretics in Torquemada's Summa are this: «schisma dicit divisionem per inobedientiam factam summo sacerdoti sive iudici Christi vicem gerenti », relying on the definition of Hostiensis : « Schisma est illicita divisio per inobedientiam ab unitate ecclesie facta. » Summa de Ecclesia IV/1, c. 1, Venedig 1561, fol. 358r. - « Haeresis sit opinio vel assertio falsa sive dogma falsum catholice veritati contrarium in eo qui christianam fidem professus est. » Ibid. IV/2, c. 1, ed. cit. 376r.

50. Summa de Ecclesia IV/2, c. 5. - The reflection takes up the expression in 1 Cor $11: 17$ : "Oportet haereses esse "

51. The method is explained very well in Thomas Aquinas, Summa contra gentiles I, 1-3. It occurs already in earlier writings, such as for instance in the prologue of Peter Lombard's Sentences.

\section{INDEX}

Mots-clés : hussitisme, Concile de Bâle, conciliarisme/papalisme, Église romaine, Jan Hus, Stanislaus de Znoimo, Staphan Pálec, Johannes Stoijkovic de Ragusa OP, Johannes de Turrecremata OP

\section{AUTEUR}

\section{THOMAS PRÜGL}

Université de Vienne (Autriche), Faculté de Théologie catholique 